\title{
HEAVY METALS AND SAFETY OF FRESH FRUITS IN BANGALORE CITY, INDIA - A CASE STUDY
}

\author{
Seyed Esmael Mahdavian*, R.K. Somashekar \\ Department of Environmental Science, Bangalore University, \\ Jnanabharati campus, Bangalore, Karnataka, India \\ *Corresponding author: ali2003_in@yahoo.com \\ Received 23 September; Revised 25 September
}

\begin{abstract}
Urban food security in India is a matter of growing concern. It is estimated that by 2005, $60 \%$ of India's population will be living in urban areas. The presence of heavy metals in human body always draws scientific concern as these are considered responsible for affecting health, especially in these days where the release of toxic wastes in the environment has been increased. The increasing trends in food contamination in urban areas are largely attributed to the polluted environment in urban agriculture, contaminated food transport and supply chains; poor market sanitary conditions, and the use of contaminated or waste water for irrigation purposes. The objectives of this paper to measure the levels of heavy metal contamination of fruits in Bangalore markets and assess how the heavy metal contamination might have impacted food safety standards vis a vis heavy metals on urban consumers. The results show that urban consumers are at greater risk of purchasing fresh fruits with high levels of heavy metals beyond the legally permissible limits as defined by the Indian Prevention of Food Adulteration Act, 1954. It must be noted here that these norms are less strict than international food safety norms like Codex Alimentarius or European Union standards. It is therefore suggested here that care should be taken in the following: reduce pollution at water source points; improve post harvest handling; enhance better coordination in fresh crops trading system to improve food safety standards; improve sanitary conditions for the city food markets; and increase awareness in consumers and policy makers on the dangers of heavy metal contamination in the food intake.
\end{abstract}

Keywords: Heavy metals; Prevention of Food Adulteration Act; Atomic Absorption Spectrophotometer (AAS)

\section{INTRODUCTION}

Food chain contamination by heavy metals has become a burning issue in recent years because of their potential accumulation in biosystems through contaminated water, soil and air (Lokeshwari, 2006). Therefore Monitoring programmes for residues and contaminants contribute to improving food safety, warn of actual and potential food scares, and facilitate evaluation of possible health hazards by providing continuous information on levels of environmental pollution in the country (Dogheim, 2004).

Urban food security in India is a matter of growing concern. It is estimated that by 2005 , $60 \%$ of India's population will be living in urban areas. The presence of heavy metals in human body always draws scientific concern as these are considered responsible for affecting health, especially in these days where the release of toxic wastes in the 
environment has been increased (Marshall, 2003). In recent years, research has been focused on accumulation of heavy metals in crop (Barman, 2000). The increasing trends in food contamination in urban areas are largely attributed to the polluted environment in urban agriculture, contaminated food transport and supply chains, poor market sanitary conditions, and the use of contaminated or waste water for irrigation purposes. The objectives of this study is to measure the levels of heavy metal contamination of fruits in Bangalore markets and assess how the heavy metal contamination might have impacted food safety standards vis a vis heavy metals on urban consumers.

\section{MATERIALS AND METHODS Sample Collection}

Fresh fruit samples were collected from the two main Bangalore City Markets of K.R. Market and Yeshwantpur Market. Sampling was done at random from different retailers and vendors within these market areas. A total of eleven (11) fruit varieties including oranges, bananas, pomegranates, lemons, pears, Chiku fruits, apples, mangoes, guavas, grapes, and mandarins, were collected in pairs from each of these market areas. Sampling was done for a total of four months between June and October of 2007. The sampling period covered the entire rainy season of the year with intent of coinciding with maximum harvest yield of the crops coming from the different sources of agriculture in the region. The fruits samples were then analyzed for $\mathrm{Cd}, \mathrm{Co}, \mathrm{Cr}, \mathrm{Cu}, \mathrm{Fe}, \mathrm{Mn}, \mathrm{Ni}, \mathrm{Pb}$, and $\mathrm{Zn}$.

\section{Sample Preparation}

The collected fruit samples were thoroughly washed and rinsed with distilled water. The samples were then sliced to small pieces and oven dried at $150 \mathrm{C}$ for 48 hours. The dried samples were then grounded into a fine powder form and stored in a fresh plastic polythene bag ready for digestion.

\section{Sample digestion}

Digestion of fruit samples for heavy metals analysis involved a high performance microwave assisted digestion using a 6 Monobloc Microwave Ethos D Labstation. In this case, $0.5 \mathrm{~g}$ of a sample was added with $4 \mathrm{ml}$ of conc. $\mathrm{HNO}_{3}$ and $0.2 \mathrm{ml}$ of Hydrogen Peroxide Solution $\left(\mathrm{H}_{2} \mathrm{O}_{2}\right)$. The solution was put in a reference reaction vessel which was then inserted into a rotor unit ready for digestion. The system was then pre-programmed using the Ethos $D$ control terminal (equipped with software) for 5 minutes of microwave digestion at $250 \mathrm{~W}$ power and then for another 5 minutes at $500 \mathrm{~W}$ power. The digested solution was then left for automatic ventilation for 10 minutes. After cooling, the samples were then filtered using Whatmann filter paper No. 40. The filtered sample was then made up to $100 \mathrm{ml}$ with metal-free distilled water and stored in a special container ready for analysis.

\section{Sample analysis of Heavy Metal content}

A Shimadzu type Atomic Absorption Spectrophotometer (AAS) 6300 model with Air$\mathrm{C}_{2} \mathrm{H}_{2}$ flame type of an average fuel flow rate of between 0.8 to $4.0 \mathrm{~L} / \mathrm{min}$ and the support gas flow rate between 13.5 to $17.5 \mathrm{~L} / \mathrm{min}$ was used. The single element hollow cathode lamps used were of Hamamatsu Photonics Co. Ltd - L2433 series. The standard references for the given elements were procured from Inorganic Ventures Inc. and Sisco Research Laboratories Mumbai Ltd. Calibration curves for various elements obtained from these standards were of first order reaction. 


\section{RESULTS AND DISCUSSION}

The results show that urban consumers are at greater risk of purchasing fresh fruits with high levels of heavy metals beyond the legally permissible limits as defined by the Indian Prevention of Food Adulteration Act, 1954. It must be noted here that these norms are less strict than international food safety norms like Codex Alimentarius or European Union standards. Average Cadmium (Cd) levels ranged between 6.05 and $11.67 \mathrm{ug} / \mathrm{g}$ dry wt with an average contamination level of 7.05. This is seven times more than the prescribed limits of the PFA Act 1954 of $1.5 \mathrm{ug} / \mathrm{g}$ dry wt. The Standard Deviation for Cd was at 2.07. Similarly the Chromium (Cr) levels ranged between $19 \mathrm{ug} / \mathrm{g}$ dry wt and 166 $\mathrm{ug} / \mathrm{g}$ dry wt with an average of $75.62 \mathrm{ug} / \mathrm{g}$ dry wt and SD of 49.0. For Cobalt (Co), the average was $40.93 \mathrm{ug} / \mathrm{g}$ dry wt; the maximum was $138 \mathrm{ug} / \mathrm{g}$ dry wt and minimum was $6.14 \mathrm{ug} / \mathrm{g}$ dry wt. SD for Co was 49.0.

Copper $(\mathrm{Cu})$, like the other metals generally enter the contaminated environment through small scale industrial effluents (including battery production, metal products, metal melting \& Cable coating industries). The maximum was $24.2 \mathrm{ug} / \mathrm{g}$ dry wt and the minimum was $1.9 \mathrm{ug} / \mathrm{g}$ dry wt. Mean value was $10.87 \mathrm{ug} / \mathrm{g}$ dry wt at SD = 7.7. In 1993, the joint FAO/WHO Expert Committee for Additives and Contaminants (JECFA) reduced the value it had provisionally specified for adults in 1972, for tolerable Lead $(\mathrm{Pb})$ consumption per week (PTWI - provisional tolerable weekly intake), from $0.05 \mathrm{mg} / \mathrm{kg}$ body weight to $0.025 \mathrm{mg}$ (or $25 \mu \mathrm{g}$ ). However, in the fresh fruit samples collected from Bangalore city markets, $\mathrm{Pb}$ levels were at an average $53.87 \mathrm{ug} / \mathrm{g}$ dry wt. The maximum was $185.64 \mathrm{ug} / \mathrm{g}$ dry wt and minimum at $8.49 \mathrm{ug} / \mathrm{g}$ dry wt with Standard Deviation of 57.17 .

The prescribed Zn level as per the PFA Act 1954 is $50 \mathrm{ug} / \mathrm{g}$ dry wt. For the collected samples, Zn levels ranged between $17.84 \mathrm{ug} / \mathrm{g}$ dry wt and $45.16 \mathrm{ug} / \mathrm{g}$ dry wt with an average of $30 \mathrm{ug} / \mathrm{g}$ dry wt and SD of 8.63. This shows that the fruits were within the permissible level of PFA Act 1954. Nickel (Ni) ranged between $9.1 \mathrm{ug} / \mathrm{g}$ dry wt and 72.5 ug/g dry wt with an average of $53.87 \mathrm{ug} / \mathrm{g}$ dry wt and SD of 57.17. Iron $(\mathrm{Fe})$, and Manganese ( $\mathrm{Mn})$ were found abundant in the samples. The maximum Iron ( $\mathrm{Fe})$ levels were at $282.18 \mathrm{ug} / \mathrm{g}$ dry wt and the minimum at $64.26 \mathrm{ug} / \mathrm{g}$ dry wt. The average value was at $167.39 \mathrm{ug} / \mathrm{g}$ dry wt with SD of 63. Nevertheless, Manganese (Mn) levels ranged between $10.8 \mathrm{ug} / \mathrm{g}$ dry wt and $344 \mathrm{ug} / \mathrm{g}$ dry wt. The average values were $61.0 \mathrm{ug} / \mathrm{g}$ dry wt and SD of 100.0 .

The above results indicate the order of abundance of heavy metals in the collected fresh fruit samples as follows: $\mathrm{Fe}>\mathrm{Cr}>\mathrm{Mn}>\mathrm{Pb}>\mathrm{Ni}>\mathrm{Co}>\mathrm{Zn}>\mathrm{Cu}>\mathrm{Cd}$. Moreover the standard deviation values also indicate higher variability in concentration ranges of the heavy metal elements as follows: $\mathrm{Mn}>\mathrm{Fe}>\mathrm{Pb}>\mathrm{Cr}>\mathrm{Co}>\mathrm{Ni}>\mathrm{Zn}>\mathrm{Cu}>\mathrm{Cd}$.

Table 1: Measurement Conditions Table for Shimadzu AAS-6300 Analysis

\begin{tabular}{|l|c|c|c|c|}
\hline \multicolumn{1}{|c|}{ Element } & $\begin{array}{c}\text { Wavelength } \\
(\mathrm{nm})\end{array}$ & $\begin{array}{c}\text { Burner Slit } \\
(\mathrm{nm})\end{array}$ & Flame type & $\begin{array}{c}\text { Flow } \\
(\mathrm{L} / \mathrm{min})\end{array}$ \\
\hline Cadmium (Cd) & 228.8 & 0.7 & Air - C2H2 & 1.8 \\
\hline Cobalt $(\mathbf{C o})$ & 240.7 & 0.2 & Air $-\mathrm{C} 2 \mathrm{H} 2$ & 1.6 \\
\hline Chromium $(\mathbf{C r})$ & 357.9 & 0.7 & Air $-\mathrm{C} 2 \mathrm{H} 2$ & 2.8 \\
\hline
\end{tabular}




\begin{tabular}{|l|c|c|c|c|}
\hline Copper (Cu) & 324.8 & 0.7 & Air - C2 2 2 & 1.8 \\
\hline Iron (Fe) & 248.3 & 0.2 & Air - C2 $2 \mathrm{H} 2$ & 1.8 \\
\hline Manganese (Mn) & 279.5 & 0.2 & Air - C2 $2 \mathrm{H} 2$ & 2.0 \\
\hline Nickel & 23.0 & 0.2 & Air - C2 2 2 & 1.6 \\
\hline Lead (Pb) & 283.3 & 0.7 & Air - C2 2 & 2.0 \\
\hline Zinc & 213.9 & 0.7 & Air $-\mathrm{C} 2 \mathrm{H} 2$ & 2.0 \\
\hline
\end{tabular}

Table 2. Average Concentrations of Heavy Metals in Fruits Collected from K.R Market in $u g g^{-1}$ Dry Weight

\begin{tabular}{|l|l|l|l|l|c|c|l|c|c|}
\hline Fruit Sample & $\mathrm{Cd}$ & $\mathrm{Cr}$ & $\mathrm{Co}$ & $\mathrm{Cu}$ & $\mathrm{Fe}$ & $\mathrm{Mn}$ & $\mathrm{Ni}$ & Pb & Zn \\
\hline Oranges & $\mathbf{1 . 8 0}$ & $\mathbf{3 2 . 8 2}$ & n.d & $\mathbf{1 5 . 1 0}$ & $\mathbf{2 2 0 . 4 7}$ & $\mathbf{5 9 . 6 3}$ & n.d & n.d & $\mathbf{3 5 . 4 3}$ \\
\hline Bananas & $\mathbf{4 . 6 4}$ & $\mathbf{3 7 . 8 7}$ & $\mathbf{6 . 0 6}$ & $\mathbf{0 . 8 8}$ & $\mathbf{8 4 . 5 3}$ & $\mathbf{1 2 . 9 9}$ & n.d & $\mathbf{1 9 5 . 1 9}$ & $\mathbf{3 2 . 0 1}$ \\
\hline Pomegranates & $\mathbf{0 . 5 1}$ & $\mathbf{6 8 . 1 6}$ & $\mathbf{8 8 . 8 8}$ & $\mathbf{2 7 . 5 5}$ & $\mathbf{1 5 2 . 5 0}$ & $\mathbf{3 5 . 2 7}$ & $\mathbf{3 4 . 4 7}$ & $\mathbf{2 6 . 9 2}$ & $\mathbf{4 4 . 6 9}$ \\
\hline Lemon & $\mathbf{4 . 6 4}$ & $\mathbf{8 8 . 3 6}$ & $\mathbf{3 1 . 3 1}$ & $\mathbf{5 . 3 3}$ & $\mathbf{1 6 2 . 9 6}$ & $\mathbf{4 2 . 9 3}$ & $\mathbf{3 1 . 6 0}$ & n.d & $\mathbf{2 2 . 1 4}$ \\
\hline Pears & $\mathbf{3 . 8 5}$ & $\mathbf{4 7 . 6 1}$ & $\mathbf{7 . 3 9}$ & n.d & $\mathbf{3 4 4 . 0 1}$ & $\mathbf{2 7 2 . 1 3}$ & $\mathbf{3 8 . 4 9}$ & $\mathbf{9 . 5 2}$ & $\mathbf{2 3 . 0 8}$ \\
\hline Chiku Fruits & $\mathbf{4 . 0 6}$ & $\mathbf{1 0 4 . 7}$ & $\mathbf{3 2 . 5 4}$ & $\mathbf{4 . 7 4 0 1}$ & $\mathbf{2 2 1 . 3 6}$ & $\mathbf{2 4 . 6 6}$ & $\mathbf{1 4 . 0 6}$ & $\mathbf{3 8 . 0 9}$ & $\mathbf{3 1 . 9 6}$ \\
\hline Apple & $\mathbf{6 . 4 2}$ & n.d & $\mathbf{3 9 . 9 3}$ & n.d & $\mathbf{2 8 6 . 5 5}$ & $\mathbf{4 3 . 1 7}$ & $\mathbf{9 7 . 7 2}$ & $\mathbf{1 9 . 0 4}$ & $\mathbf{2 8 . 0 5}$ \\
\hline Mangoes & $\mathbf{2 . 1 4}$ & $\mathbf{8 5 . 7 1}$ & n.d & $\mathbf{1 4 . 2 2}$ & $\mathbf{1 8 9 . 3 1}$ & $\mathbf{3 9 . 3 1}$ & $\mathbf{1 4 . 0 6}$ & $\mathbf{9 . 5 2}$ & $\mathbf{3 2 . 6 7}$ \\
\hline Guavas & $\mathbf{3 . 8 5}$ & n.d & $\mathbf{5 1 . 7 6}$ & n.d & $\mathbf{2 1 3 . 6 2}$ & $\mathbf{3 5 . 4 6}$ & $\mathbf{4 6 . 6 4}$ & $\mathbf{9 . 5 2}$ & $\mathbf{3 8 . 5 3}$ \\
\hline Grapes & $\mathbf{3 . 6 3}$ & $\mathbf{2 8 . 5 7}$ & $\mathbf{5 4 . 7 2}$ & n.d & $\mathbf{2 0 6 . 9 9}$ & $\mathbf{3 9 . 3 1}$ & $\mathbf{4 4 . 4 2}$ & $\mathbf{5 7 . 1 4 2}$ & $\mathbf{1 7 . 4 0}$ \\
\hline
\end{tabular}

Table 3. Average Concentrations of Heavy Metals in Fruits collected from Yeshwantpur Market in ug $\mathbf{~ g}^{-1}$

Dry Wt.

\begin{tabular}{|l|l|l|l|l|l|l|l|l|c|}
\hline Fruit Sample & Cd & \multicolumn{1}{c|}{$\mathrm{Cr}$} & \multicolumn{1}{c|}{ Co } & Cu & \multicolumn{1}{c|}{$\mathrm{Fe}$} & \multicolumn{1}{c|}{$\mathrm{Mn}$} & $\mathrm{Ni}$ & $\mathrm{Pb}$ & $\mathrm{Zn}$ \\
\hline Oranges & $\mathbf{1 5 . 3 9}$ & $\mathbf{6 1 . 2 5}$ & $\mathbf{1 5 . 2 4 1}$ & $\mathbf{1 2 . 7 8}$ & $\mathbf{1 1 4 . 0 4}$ & $\mathbf{1 7 . 5 1}$ & $\mathbf{3 3 . 2 0}$ & $\mathbf{7 0 . 4 4}$ & $\mathbf{2 2 . 0 1}$ \\
\hline Bananas & $\mathbf{1 3 . 3 6}$ & $\mathbf{8 8 . 3 2}$ & $\mathbf{1 8 5 . 9 0}$ & $\mathbf{1 4 . 1 9}$ & $\mathbf{1 9 0 . 9 9}$ & $\mathbf{4 1 7 . 3 9}$ & $\mathbf{8 . 9 0}$ & $\mathbf{7 . 4 6}$ & $\mathbf{4 5 . 6 4}$ \\
\hline Pomegranates & $\mathbf{5 . 5 9}$ & $\mathbf{1 4 0 . 0 0}$ & $\mathbf{1 5 . 2 4 1}$ & $\mathbf{4 . 5 1}$ & $\mathbf{8 0 . 5 4}$ & $\mathbf{3 4 . 5 6}$ & $\mathbf{2 6 . 8 7}$ & $\mathbf{1 7 6 . 1 0}$ & $\mathbf{3 1 . 4 4}$ \\
\hline Lemon & $\mathbf{9 . 0 9}$ & $\mathbf{2 2 7 . 5 0}$ & $\mathbf{8 . 7 0}$ & $\mathbf{6 . 7 6}$ & $\mathbf{4 3 . 9 9}$ & $\mathbf{1 1 . 0 5 9}$ & $\mathbf{3 7 . 9 4}$ & $\mathbf{5 8 . 7 0}$ & $\mathbf{2 2 . 1 9}$ \\
\hline Pears & $\mathbf{7 . 5 8}$ & $\mathbf{8 8 . 3 2}$ & n.d & $\mathbf{1 3 . 0 7}$ & $\mathbf{1 7 0 . 3 9}$ & $\mathbf{6 3 . 7 6}$ & n.d & $\mathbf{2 6 . 1 3}$ & $\mathbf{2 4 . 0 8}$ \\
\hline Chiku Fruits & $\mathbf{9 . 4 4}$ & $\mathbf{5 0 . 1 0}$ & n.d & $\mathbf{1 2 . 3 2}$ & $\mathbf{1 3 4 . 8 7}$ & $\mathbf{1 1 . 5 9}$ & $\mathbf{4 . 3 2}$ & $\mathbf{2 9 . 8 6}$ & $\mathbf{2 3 . 9 0}$ \\
\hline Apple & $\mathbf{8 . 3 9}$ & $\mathbf{8 . 7 5 0}$ & $\mathbf{2 5 . 4 0}$ & $\mathbf{3 . 0 0}$ & $\mathbf{1 2 1 . 1 5}$ & $\mathbf{8 . 7 5}$ & $\mathbf{4 7 . 4 3}$ & $\mathbf{2 3 . 4 8}$ & $\mathbf{3 5 . 8 8}$ \\
\hline Mangoes & $\mathbf{1 6 . 9}$ & $\mathbf{3 7 . 3 6}$ & $\mathbf{6 . 2 3}$ & $\mathbf{6 . 3 4}$ & $\mathbf{7 5 . 1 6}$ & $\mathbf{1 1 . 5 9}$ & n.d & $\mathbf{6 7 . 2 0}$ & $\mathbf{1 8 . 2 9}$ \\
\hline Guavas & $\mathbf{7 . 5 8}$ & $\mathbf{2 7 . 1 7}$ & n.d & $\mathbf{2 0 . 9 1}$ & $\mathbf{2 2 0 . 3 6}$ & $\mathbf{1 0 . 8 6}$ & $\mathbf{2 4 . 1 7}$ & n.d & $\mathbf{2 8 . 9 7}$ \\
\hline Grapes & $\mathbf{1 2 . 2 4}$ & $\mathbf{1 6 6 . 2 5}$ & n.d & n.d & $\mathbf{1 1 4 . 0 4}$ & $\mathbf{2 9 . 0 3}$ & $\mathbf{3 7 . 1 5}$ & $\mathbf{9 9 . 7 9}$ & $\mathbf{4 1 . 4 3}$ \\
\hline
\end{tabular}


Table 4. Total Concentrations of Heavy Metals in

Fruits collected from K.R and Yeshwantpur Markets.

K.R. Market Fruit Samples

\begin{tabular}{|l|l|c|c|c|c|c|l|c|c|}
\hline & $\mathrm{Cd}$ & $\mathrm{Cr}$ & $\mathrm{Co}$ & $\mathrm{Cu}$ & $\mathrm{Fe}$ & $\mathrm{Mn}$ & $\mathrm{Ni}$ & $\mathrm{Pb}$ & $\mathrm{Zn}$ \\
\hline $\begin{array}{l}\text { Maximum in } \\
\text { ug g }^{-1} \text { dry wt }\end{array}$ & 6.42 & 104.76 & $\mathbf{8 8 . 8 8}$ & 27.55 & 344.01 & 272.13 & 97.72 & 195.19 & 44.69 \\
\hline $\begin{array}{l}\text { Minimum in } \\
\text { ug g }^{-1} \text { dry wt }\end{array}$ & $\mathbf{0 . 5 1}$ & 28.57 & 6.06 & $\mathbf{0 . 8 8}$ & $\mathbf{8 4 . 5 3}$ & 12.99 & 14.06 & 9.52 & 17.40 \\
\hline $\begin{array}{l}\text { Mean in ug g } \\
\text { dry wt }\end{array}$ & 3.55 & 61.73 & 39.07 & 11.30 & 208.23 & 60.49 & 40.18 & 45.62 & 30.59 \\
\hline $\begin{array}{l}\text { Standard } \\
\text { Deviation }\end{array}$ & 1.68 & 28.99 & 26.95 & 9.74 & 71.29 & 75.35 & 26.31 & 62.71 & 8.18 \\
\hline
\end{tabular}

Yeshwantpur Market Fruit Samples

\begin{tabular}{|l|l|l|l|l|l|l|l|l|l|}
\hline $\begin{array}{l}\text { Maximum in } \\
\text { ug g }^{-1} \text { dry wt }\end{array}$ & 16.90 & 227.5 & 185.90 & 20.91 & 220.36 & 417.39 & 47.43 & 176.10 & 45.64 \\
\hline $\begin{array}{l}\text { Minimum in } \\
\text { ug g }^{-1} \text { dry wt }\end{array}$ & 5.59 & 8.75 & 6.23 & 3.00 & 43.99 & 8.75 & 4.32 & 7.46 & 18.29 \\
\hline $\begin{array}{l}\text { Mean in ug } \text { g }^{-1} \\
\text { dry wt }\end{array}$ & 10.56 & 89.501 & 42.78 & 10.43 & 126.55 & 61.61 & 27.50 & 62.13 & 29.38 \\
\hline $\begin{array}{l}\text { Standard } \\
\text { Deviation }\end{array}$ & 3.72 & 69.09 & 70.43 & 5.70 & 54.63 & 126.16 & 14.77 & 51.64 & 9.09 \\
\hline
\end{tabular}

Total Samples

\begin{tabular}{|l|l|l|l|l|l|l|l|l|l|}
\hline $\begin{array}{l}\text { Maximum in } \\
\text { ug g }^{-1} \text { dry wt }\end{array}$ & 11.66 & 166.13 & 137.39 & 24.23 & 282.18 & 344.76 & 72.57 & 185.64 & 45.16 \\
\hline $\begin{array}{l}\text { Minimum in } \\
\text { ug g } \text { g dry wt }^{-1}\end{array}$ & 3.05 & 18.66 & 6.14 & 1.94 & 64.26 & 10.87 & 9.19 & 8.49 & 17.84 \\
\hline $\begin{array}{l}\text { Mean in ug g } \\
\text { dry wt }\end{array}$ & 7.05 & 75.62 & 40.93 & 10.87 & 167.39 & 61.05 & 33.84 & 53.87 & 29.99 \\
\hline $\begin{array}{l}\text { Standard } \\
\text { Deviation }\end{array}$ & 2.70 & 49.03 & 48.68 & 7.72 & 62.95 & 100.75 & 20.53 & 57.17 & 8.63 \\
\hline
\end{tabular}



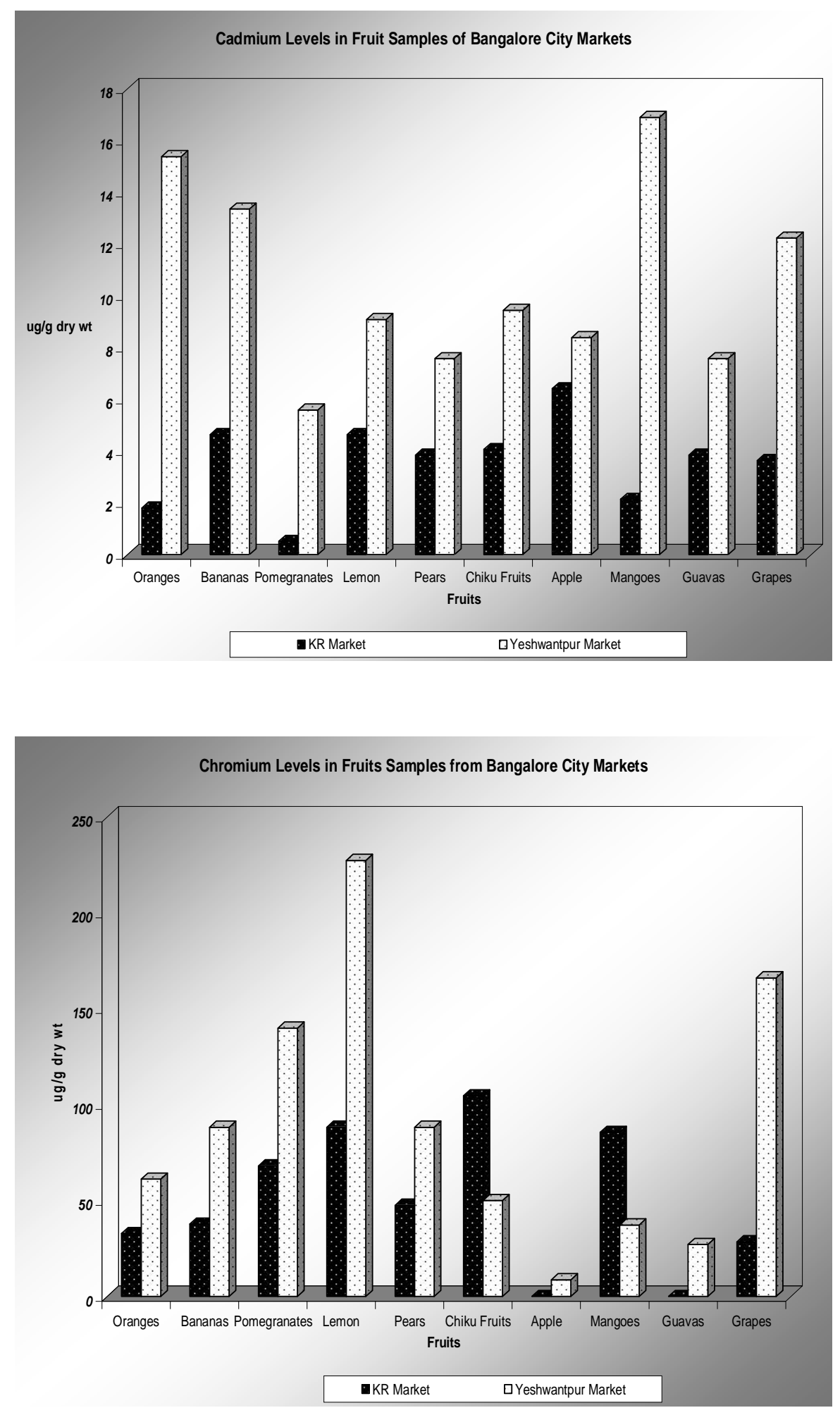
KATHMANDU UNIVERSITY JOURNAL OF SCIENCE, ENGINEERING AND TECHNOLOGY

VOL. I, No. V, SEPTEMBER 2008, pp 17-27.
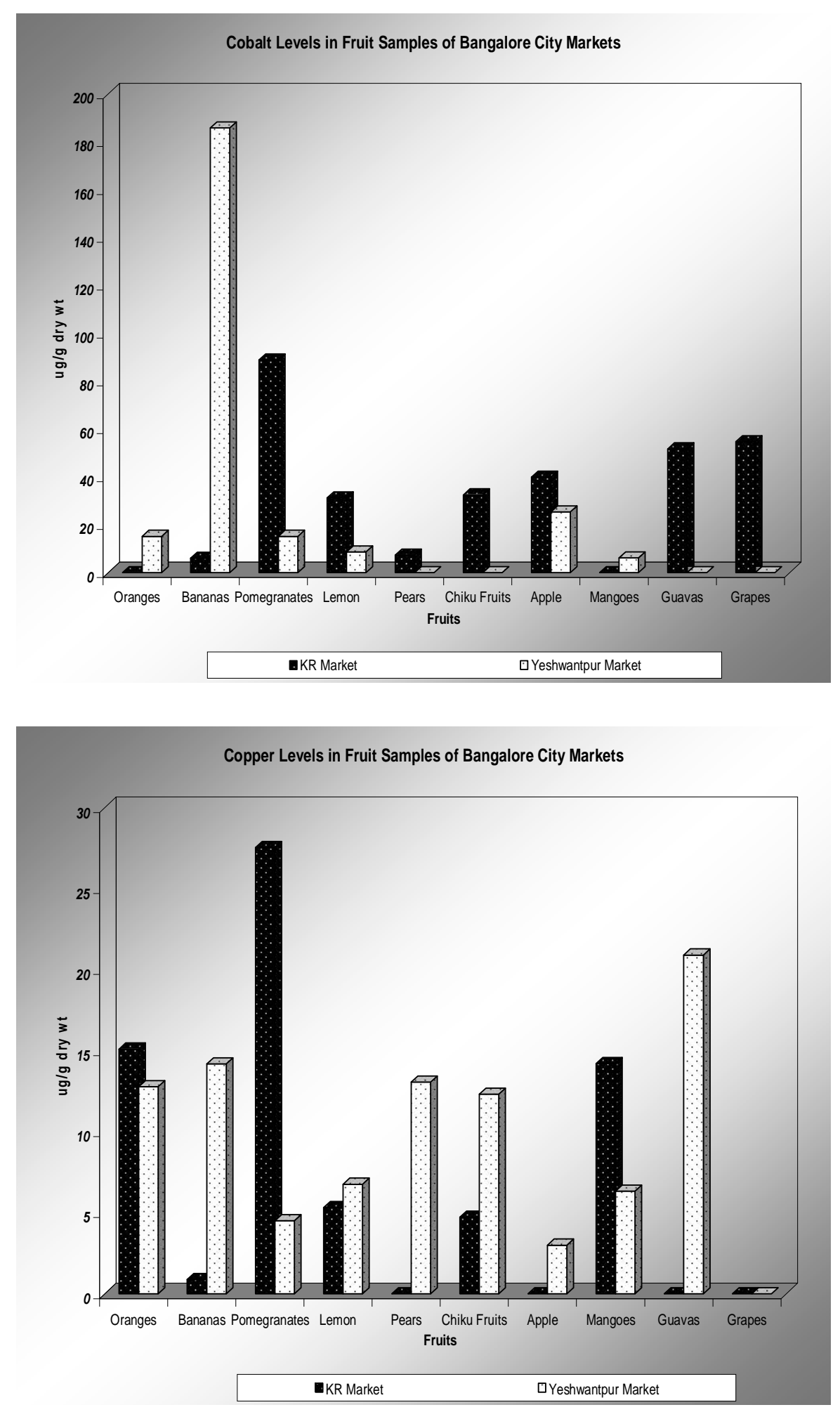

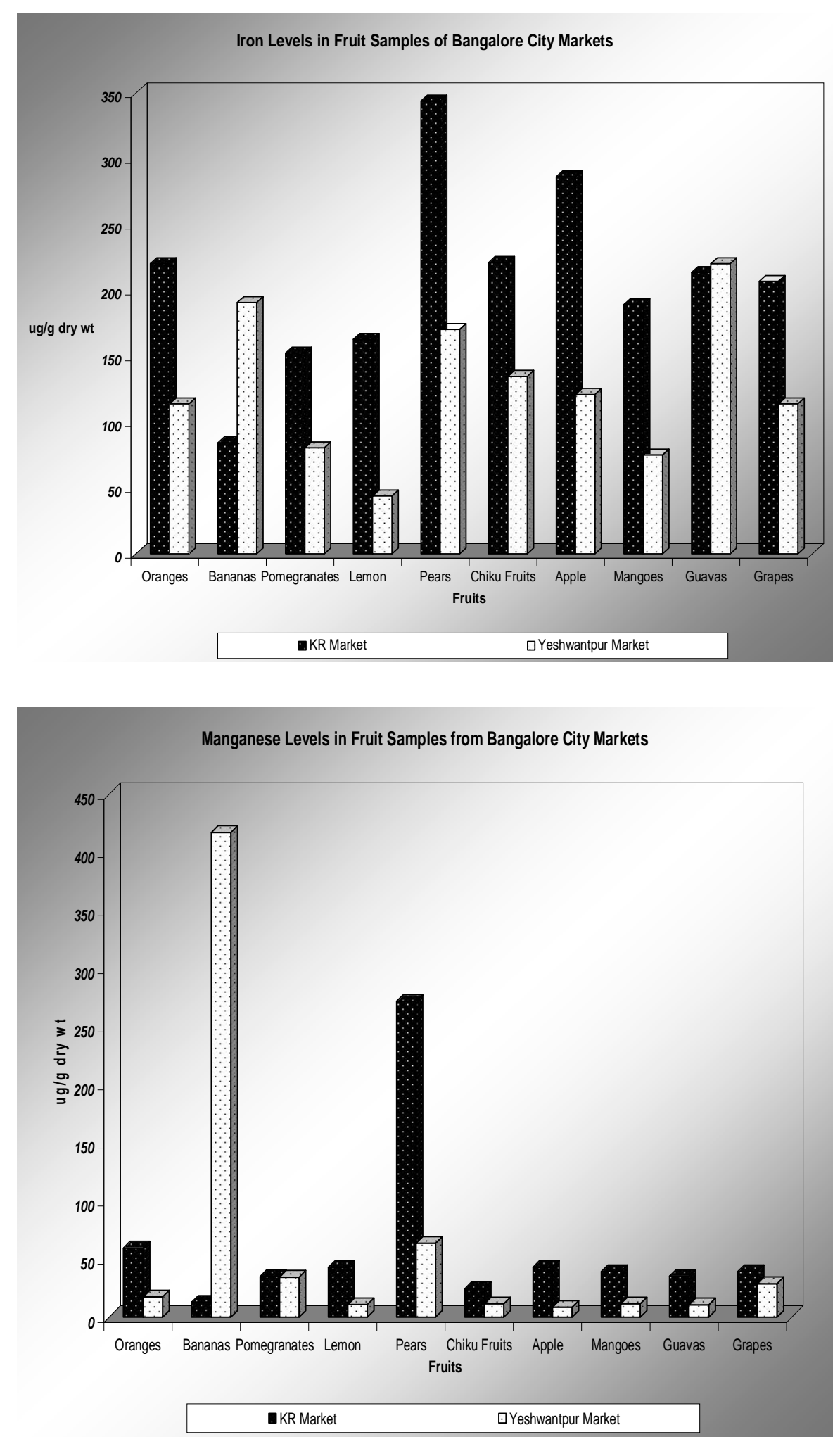
KATHMANDU UNIVERSITY JOURNAL OF SCIENCE, ENGINEERING AND TECHNOLOGY

VOL. I, No. V, SEPTEMBER 2008, pp 17-27.
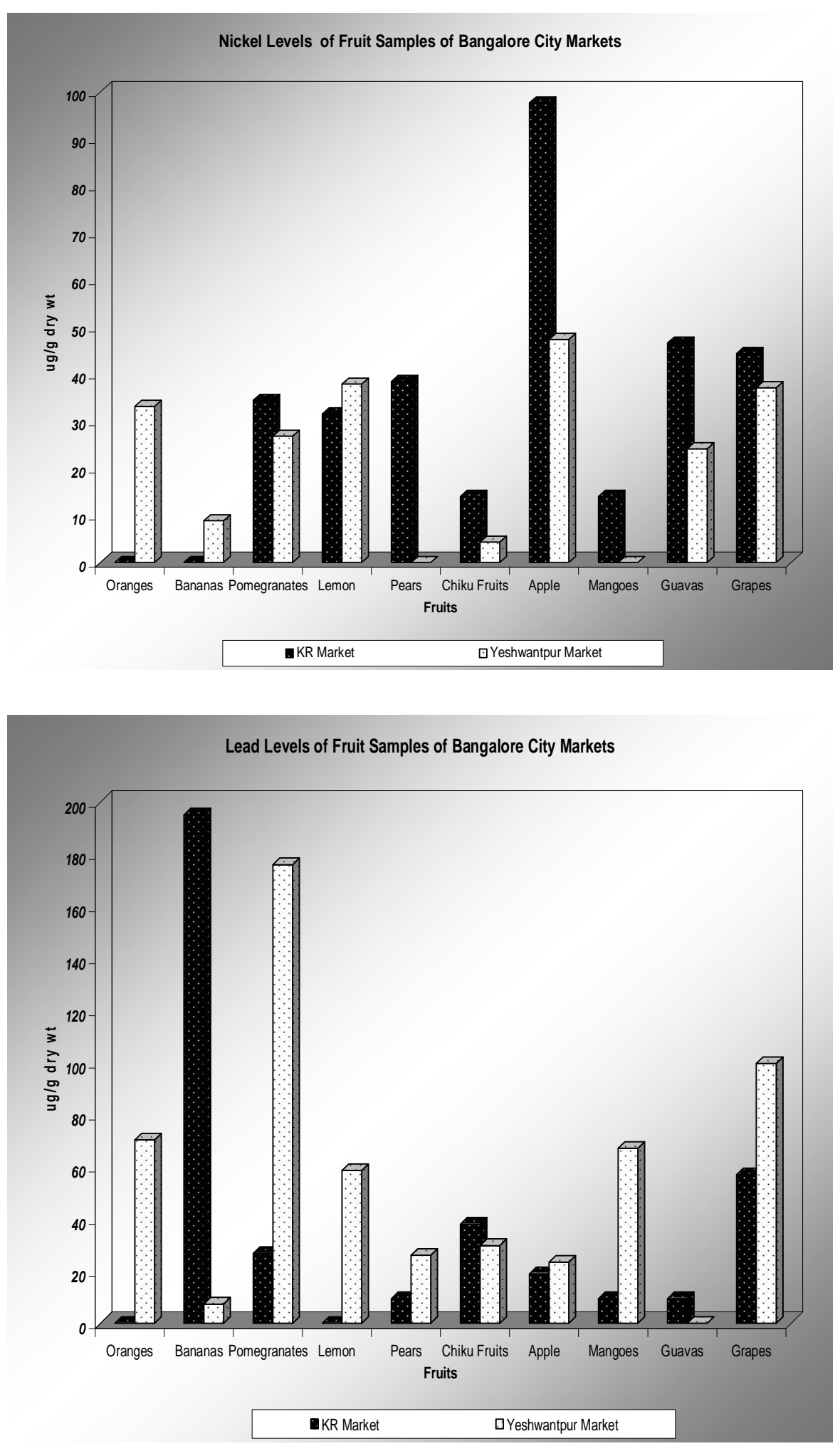


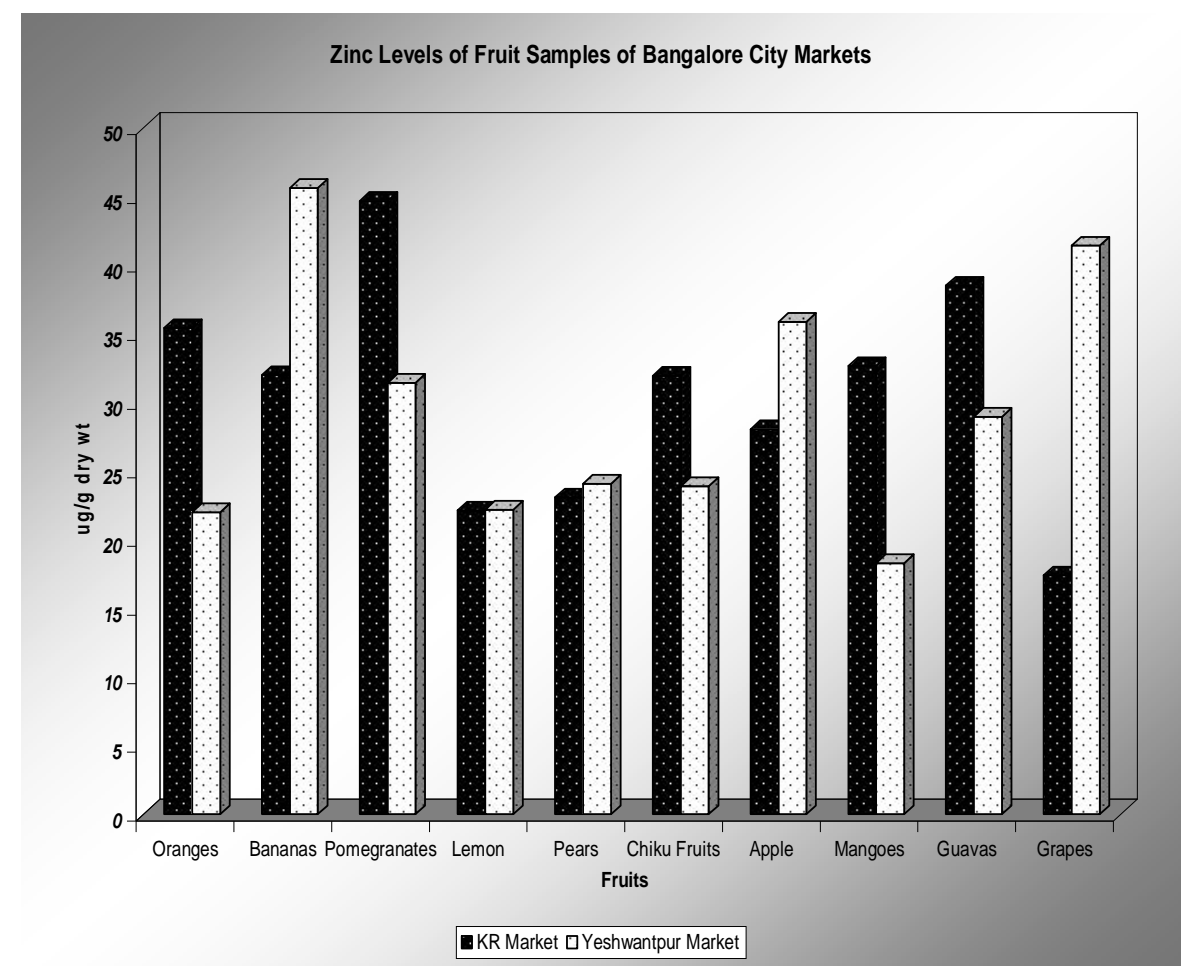

\section{CONCLUSIONS}

The above study reveals the high exposure of fresh fruit products to the heavy metals. According to Marshall, 2003, the crops are often grown in polluted and degraded environmental conditions in agricultural zones and are subject to further pollution from vehicles and industries during packaging, supplying and marketing. Another factor is the fact that most farmlands nowadays are heavily irrigated using mechanized pumps; and although this has helped increase agricultural production, the water economy plays a critical part in determining the quality of water being used. The problem arises when that irrigation water comes from sewage and industrial fed lakes, rivers, or contaminated ground water. In case of the fruit samples collected from the selected Bangalore markets, we believe that a combination of factors including the use of polluted water, bad practice in post harvesting handling of the fruit products with disregard to the food safety guidelines, and the physical market environments in these locations surrounded by a heavy urban pollution deposition may have exacerbated contamination levels of these fruit samples. As outlined in Marshall et al (2003), care should be taken in the following: reduce pollution at water source points; improve post harvest handling; enhance better coordination in fresh crops trading system to improve food safety standards; improve sanitary conditions for the city food markets; and increase awareness in consumers and policy makers on the dangers of heavy metal contamination in the food intake.

\section{REFERENCES}

1. Marshall Fiona, Ravi Agarwal, Dolf te Lintelo, D S Bhupal, Dr Rana P B Singh, Neela Mukherjee, Chandra Sen, Dr Nigel Poole, Dr Madhoolika Agrawal, S D 
Singh, 2003. Heavy Metals Contamination of Vegetables in Delhi. Technical Report of UK Department for International Development, 48-51.

2. Lokeshwari, H, G.T. Chandrappa, 2006. Impact of Heavy Metal Contamination of Bellandur Lake on Soil and Cultivated Vegetation; Current Science, 91(5), 622 627.

3. S. M. Dogheim; El M. M. Ashraf; S. A. G. Alla; M. A. Khorshid; and S. M. Fahmy, 2004. Pesticides and heavy metals levels in Egyptian leafy vegetables and some aromatic medicinal plants; Food Additives and Contaminants, 21, (4), 323330.

4. S. C. Barman, R. K. Sahu, S. K. Bhargava, C. Chaterjee, 2000. Distribution of Heavy Metals in Wheat, Mustard, and Weed Grown in Field Irrigated with Industrial Effluents; Bull. Environ. Contam. Toxicol. 64: 489-496. 